IRA-International Journal of Technology \& Engineering

ISSN 2455-4480; Vol.03, Issue 03 (2016)

Institute of Research Advances

http://research-advances.org/index.php/IRAJTE

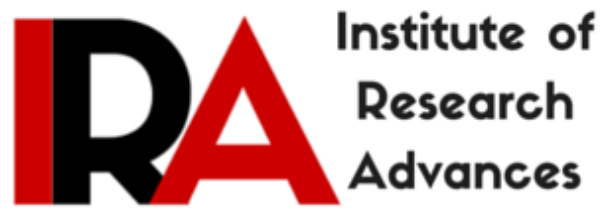

\title{
An Analytical and Numerical Investigation on Punching Shear Behaviour of SCC Slab
}

\author{
${ }^{\mathbf{1}}$. Kavinkumar, ${ }^{\mathbf{2}}$ R. Elangovan \\ ${ }^{1}$ PG Student, Structural Engineering, \\ Dr. Mahalingam College Of Engineering \& Technology, \\ Pollachi, Tamilnadu, India. \\ ${ }^{2}$ Assistant professor, Structural Engineering, \\ Dr. Mahalingam College Of Engineering \& Technology, Pollachi, Tamilnadu, India.
}

DOI: http://dx.doi.org/10.21013/jte.v3.n3.p11

\section{How to cite this paper:}

Kavinkumar, V., \& Elangovan, R. (2016). An Analytical and Numerical Investigation on Punching Shear Behaviour of SCC Slab. IRA-International Journal of Technology \& Engineering (ISSN 2455-4480), 3(3). doi:http://dx.doi.org/10.21013/jte.v3.n3.p11

(C) Institute of Research Advances

(cc) EY-NC

This works is licensed under a Creative Commons Attribution-Non Commercial 4.0 International License subject to proper citation to the publication source of the work.

Disclaimer: The scholarly papers as reviewed and published by the Institute of Research Advances (IRA) are the views and opinions of their respective authors and are not the views or opinions of the IRA. The IRA disclaims of any harm or loss caused due to the published content to any party. 


\begin{abstract}
This research is to study the mechanical properties of Self Compacting Concrete (SCC) as well as punching shear failure of SCC slabs. Self compacting concrete was first invited in 1988 to achieve durable concrete structures .Design of Reinforced concrete slab is often compromised by their ability to resist shear stress at punching shear surface area. The connection between slabs and supporting columns could be susceptible to high shear stress and might cause sudden and brittle failure. Punching shear failure takes the form of truncated pyramid shape. This program includes investigating the effect of SCC, slab thickness on the punching shear behaviour in terms of load-deflection response and ultimate failure load, failure characteristic of punching shear failure (shape of failure zone and size of failure zone) of simply supported slabs of $1000 \times 1000 \times 50$ and $75 \mathrm{~mm}$ under concentrated load at centre of slab. The slabs are made with both SCC and Conventional concrete (CC). Investigation included two way specimens with different thickness to evaluate the performance of specimen with different thickness and the effect of thickness on punching shear capacity and performance.
\end{abstract}

Keywords: punching shear failure, brittle failure, critical section, self compacting concrete, truncated pyramid shape, shear stress.

\title{
1. INTRODUCTION
}

\subsection{GENERAL}

Reinforced concrete slabs is an efficient economical structural component in any structural frames used in buildings. Modern structural systems are highly complex in configurations and are highly stressed due to heavy loadings and large spans. This results in larger sections for structural members and thus dense reinforcement to resist forces with normal strength concrete which intern increases the dead load on the foundation. Therefore use of high strength self compacting concrete for concrete structures has proven very popular in recent years. Reinforced concrete slabs may be carried directly by the columns without using beam drop panel or column capital such slabs are described as flat plates. This type of structures has more space in addition to its pleasant appearance. Flat plates have been widely used due reduced construction cost. They are also economical in their form work lead to simpler arrangement of flexural reinforcement. An additional dead load is reduced on columns and foundations.

One of the major problems in such structure is punching shear failure also known as two way shear failure that takes place when a plug of concrete is pushed out from the slab immediately above the columns. The pushed plug takes the form of pyramid. Punching shear failure is sudden and leads to progressive failure of flat slab therefore attention should be given on punching shear failure during the design of flat slabs

\subsection{PAST RESEARCH ON SELF COMPACTION CONCRETE}

The durability of concrete structures was a major topic of interest in Japan. The creation of durable concrete structures requires adequate compaction by skilled workers. The gradual reduction in the number of skilled labors construction industry has led to a similar reduction in the quality of construction work. Achievement of durable concrete structures independent of quality of construction work employment of self compacting concrete which can be compacted into every corner of a formwork, purely by means of its own weight and without the need for vibrating 
compaction. The necessity of this tpe of concrete was proposed by Okamura in 1986 . Studies to develop self compacting concrete including a fundamental study on the workability of concrete have been carried out by Ozawa and Maekawa at the University of Tokyo. The prototype of self compacting concrete was first completed in 1988 using materials already on market regard to drying and hardening shrinkage, heat of hydration, denseness after hardening and other properties. This concrete was named high performance concrete and was defined as follows at the stages of concrete

1. Fresh : self compactable

2. Early age : avoidance of initial defects

3. After hardening : protection against external factors

At almost the same time high performance concrete was defined as a concrete with high durability due to a low water cement ratio. Since then, the term high performance concrete has been used around the world to refer high durability concrete.

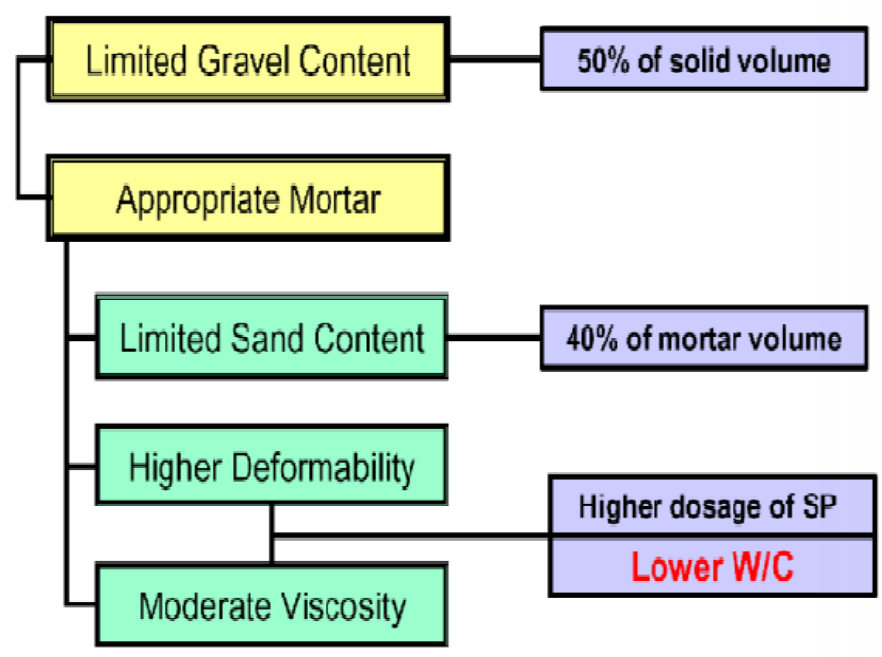

\subsection{COMPOSITION OF SELF COMPACTING CONCRETE}

Regular Concrete

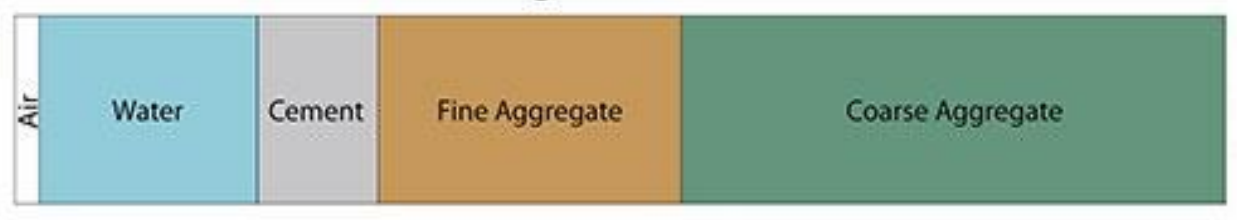

SCC

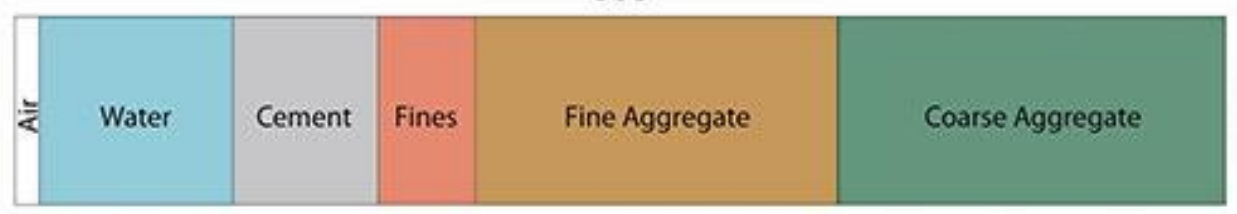

Figure 1 Volumetric ratio proportion between CC and SCC 
QUANTIFICATION OF THE PASSING ABILITY: It was already mentioned that SCC has to have the ability to flow through narrow openings without hindrance. This means that the so-called blocking of coarse aggregates through bridging has to be avoided.
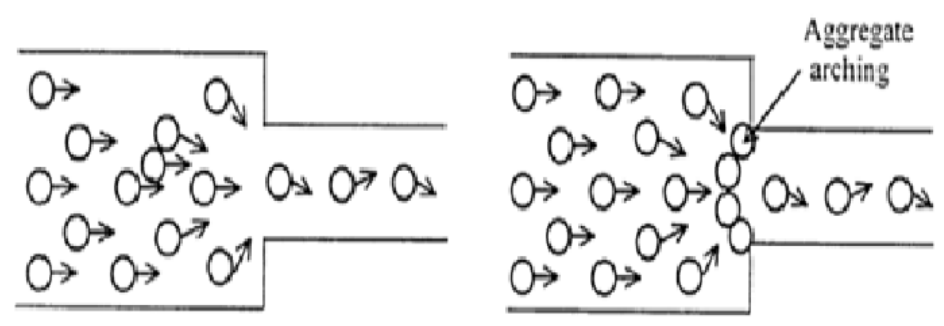

Figure 2 Mechanism of Blocking

To avoid this arching effect or blocking viscosity modifying agent is used in self compacting concrete

\section{GENERAL DESCRIPTION OF PUNCHING SHEAR}

Punching shear is a type of failure of reinforced concrete slabs subjected to high localized forces. In flat slab structures this occurs at column support points. The failure is due to shear.

\section{Punching Shear in Flat Slabs}

A typical flat plate punching shear failure is characterized by the slab failing at the intersection point of the column. This results in the column breaking through the portion of the surrounding slab. This type of failure is one of the most critical problems to consider when determining the thickness of flat plates at the column-slab intersection. Accurate prediction of punching shear strength is a major concern and absolutely necessary for engineers so they can design a safe structure.

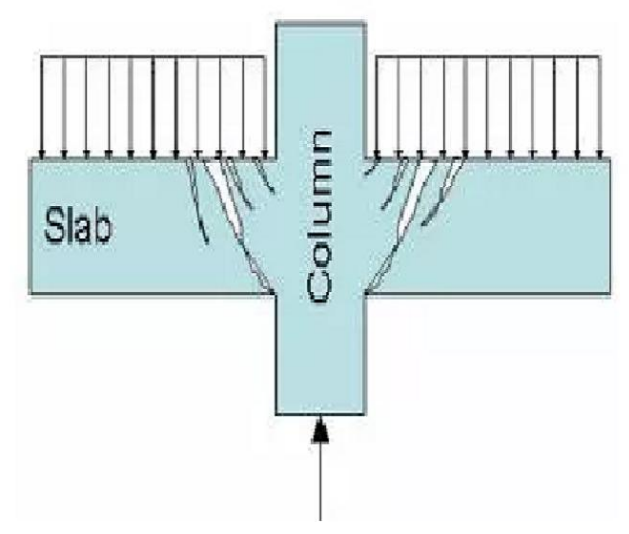

Figure 3 Punching shear failure

\section{OBJECTIVE AND SCOPE OF THE PROJECT}

1. To study the basic properties of SCC- compressive strength split tensile strength and flexural strength.

2. Experimental investigation of self-compacting concrete

3. Analytical and Numerical investigation on Punching shear failure 
4. Comparison of experimental and analytical investigation

\section{FEM MODELING PROCEDURE}

The basic concept of fem modelling is the subdivision of the mathematical model in to disjoint components of simple geometry. The response of each element is expressed in terms of a finite number of degrees of freedom characterized as the value of an unknown function, or functions or a set of nodal points. The response of the mathematical model is then considered to be the discrete model obtained by connecting or assembling the collection of all elements. Within the frame work of the finite element method reinforced concrete can be represented either by superimposition of the material models for the constituent parts, or by a constitutive law for the composite concrete, embedded steel as a continuum. To create the finite model to run properly. Models can be created using command prompt line input or the graphical user interface (GUI). For this model, the GUI was utilized to create the model. This section describes the different tasks and entries into used to create the FE calibration model.

\section{MODELING OF SLAB}

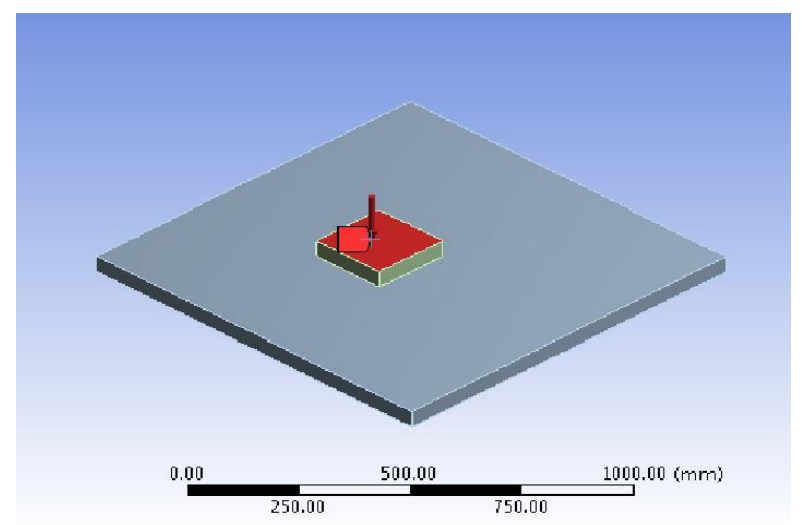

Figure 4 Loading method for slab

\section{DISCRIPTION OF ANALYTICAL PROGRAM}

Reinforced self compacting concrete slab of size $1 \mathrm{~m} \times 1 \mathrm{~m} \times 50 \mathrm{~mm}$ and $75 \mathrm{~mm}$ is created by using ANSYS v14.5. and simply supported boundary condition is analysed using finite element method.

Slabs are modelled using 8 nodded solid 65 element and link 8 elements are modelled as reinforcements.

\section{Model 1 :}

Slab dimension 1000 x 1000 x 50 mm

Concrete grade M30

Wire mesh at $10 \mathrm{~mm} \mathrm{C/C}$ distance of dia $5 \mathrm{~mm}$

\section{Model 2 :}

Slab dimension 1000 x 1000 x 75mm

Concrete grade M30 
Wire mesh at $10 \mathrm{~mm} \mathrm{C/C}$ distance of dia $5 \mathrm{~mm}$

\section{RESULTS}

\subsection{STRESS PLOT MODEL 1}

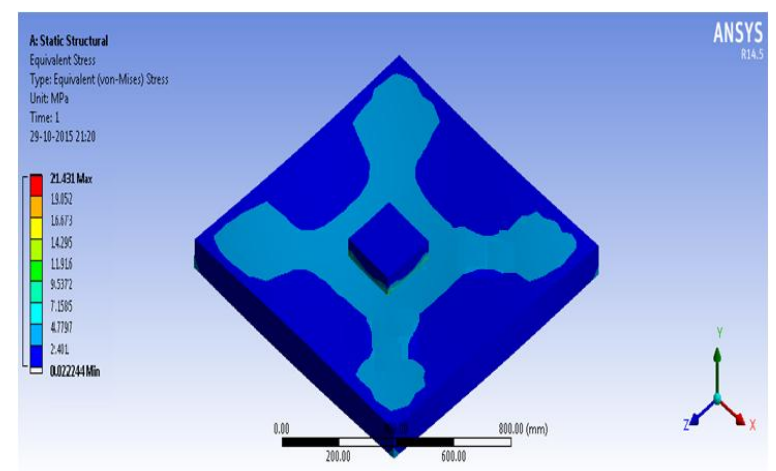

Figure 5 Stress plot for slab 50mm thickness

\section{STRESS PLOT MODEL 2}

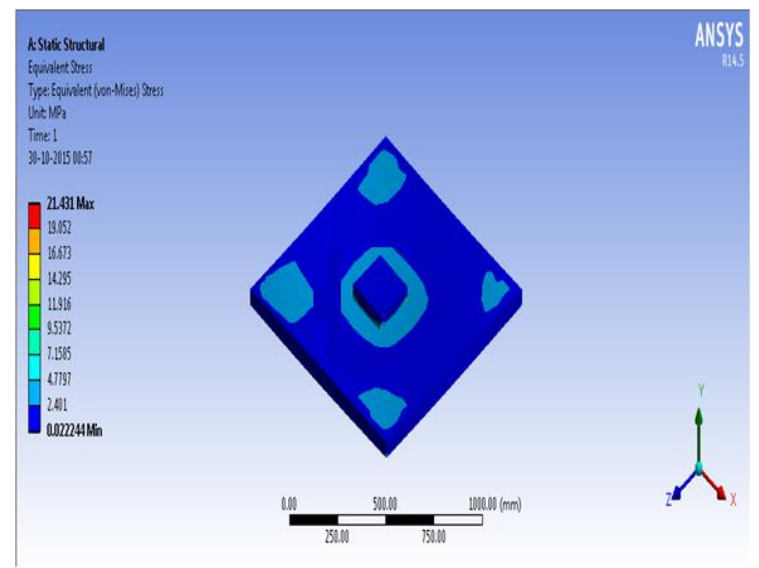

Figure 6 Stress plot for slab $75 \mathrm{~mm}$ thickness 


\subsection{DEFLECTION}

\section{MODEL 1}

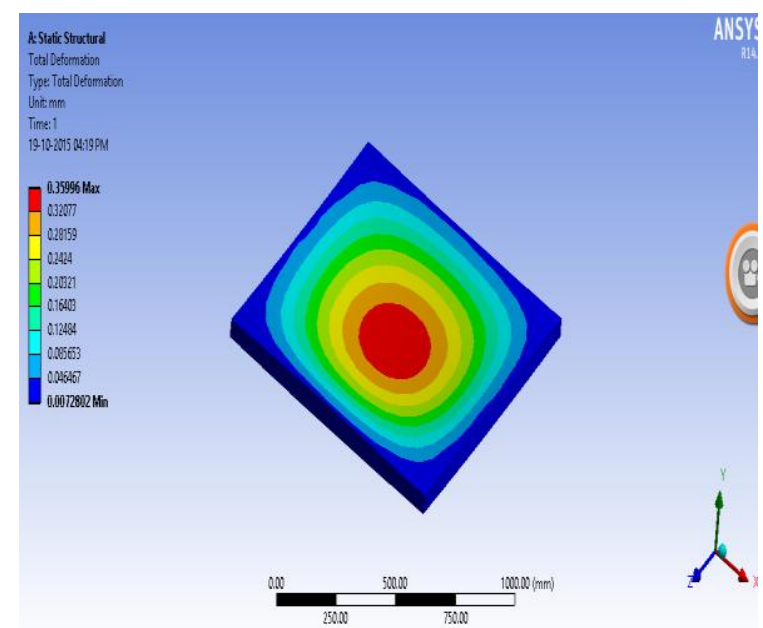

Figure 7 Deflection for slab 50mm thickness

\section{MODEL 2}

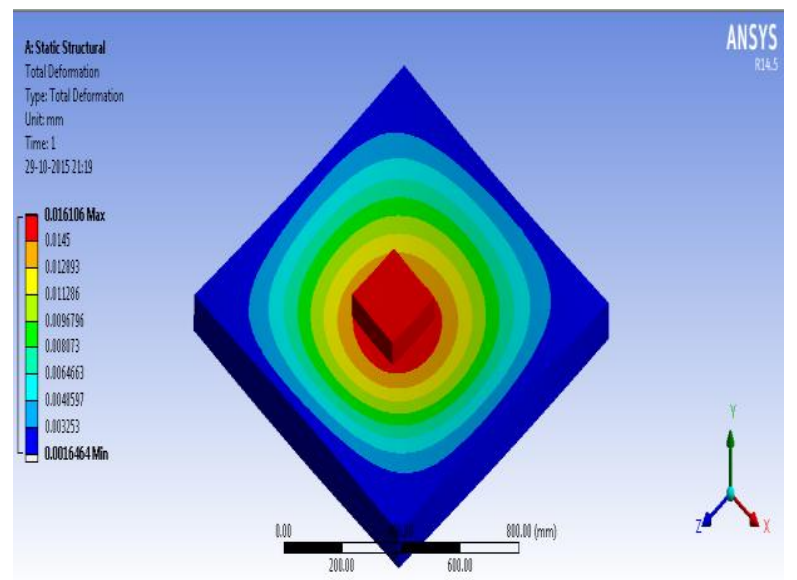

Figure 8 Deflection for slab $75 \mathrm{~mm}$ thickness

\section{NUMERICAL INVESTIGATION OF SCC SLABS}

\subsection{GENERAL}

This chapter includes manual calculation of design mix for SCC, Ultimate failure load, shear crack zone, steel reinforcement ratio, critical section

\section{Analysis of beams according to ACI 318M-02}

The ACI 318M-02 [13] adopts a relation between concrete tensile strength (split test) and the square root of the compressive strength 


\section{ULTIMATE PUNCHING LOAD FOR SLABS}

$P_{u}=\frac{\left(0.3321 X \sqrt{f_{c}} X b_{o} X d\right)}{10}$

$\boldsymbol{f}_{c^{-}}$Characteristic strength of concrete

$\boldsymbol{b}_{\boldsymbol{o}^{-}} 4(\mathrm{c}+\mathrm{d})-$ perimeter where punching shear occurs

$\boldsymbol{d}$-Effective depth of slab

$\boldsymbol{c}$ - Column length

TABLE (2) DETAILS OF SLABS PRESENT IN THE INVESTIGATION

\begin{tabular}{|c|c|c|c|c|}
\hline $\begin{array}{l}\text { GROUP } \\
\text { NO }\end{array}$ & $\begin{array}{l}\text { SLAB } \\
\text { DESIGNATION }\end{array}$ & $\begin{array}{l}\text { STEEL } \\
\text { REINFORCEMENT }\end{array}$ & $\begin{array}{l}\text { STEEL } \\
\text { REINFORCEMENT } \\
\text { RATIO }\end{array}$ & $\begin{array}{l}\text { SLAB } \\
\text { THICKNESS }\end{array}$ \\
\hline \multirow{2}{*}{$\begin{array}{l}\text { GROUP } \\
\text { ONE } \\
\text { (CC } \\
\text { SLABS) } \\
\end{array}$} & S1 & $\begin{array}{l}\varnothing 4 \mathrm{~mm} @ 100 \mathrm{~mm} \\
\mathrm{c} / \mathrm{c}\end{array}$ & 0.0033 & 50 \\
\hline & S2 & $\begin{array}{l}\varnothing 4 \mathrm{~mm} @ 100 \mathrm{~mm} \\
\mathrm{c} / \mathrm{c}\end{array}$ & 0.0033 & 75 \\
\hline \multirow{2}{*}{$\begin{array}{l}\text { GROUP } \\
\text { TWO } \\
\text { (SCC } \\
\text { SLABS) }\end{array}$} & S3 & $\begin{array}{l}\emptyset 4 \mathrm{~mm} @ 100 \mathrm{~mm} \\
\mathrm{c} / \mathrm{c}\end{array}$ & 0.0033 & 50 \\
\hline & S4 & $\begin{array}{l}\text { Ø 4mm@100 mm } \\
\mathrm{c} / \mathrm{c}\end{array}$ & 0.0033 & 75 \\
\hline
\end{tabular}

\subsection{CRITICAL SECTION}

The distance of the critical section for the slabs tested in this investigation is considered as half the distance between the end of the failure surface and the face of the column. The calculated distances are based on the measured area in ACI 318M-11 code, the critical punching shear section is assumed to be located at distance $\mathrm{d} / 2$ and $1.5 \mathrm{~d}$ from the column face, respectively the critical section equal to $2 \mathrm{~d}$ for high strength concrete.

The critical section perimeter ranged from $1.16 \mathrm{~h}$ to $1.5 \mathrm{~h}$ for slabs.

$A=r^{2}+4 r x+\pi x^{2}$

$x=\frac{-4 r+\sqrt{\left(4 r^{2}\right)-4 x \pi x\left(r^{2}-A\right)}}{2 x \pi}$

$\boldsymbol{A}$-area of failure zone

$\boldsymbol{r}$ - Radius or side length of column 


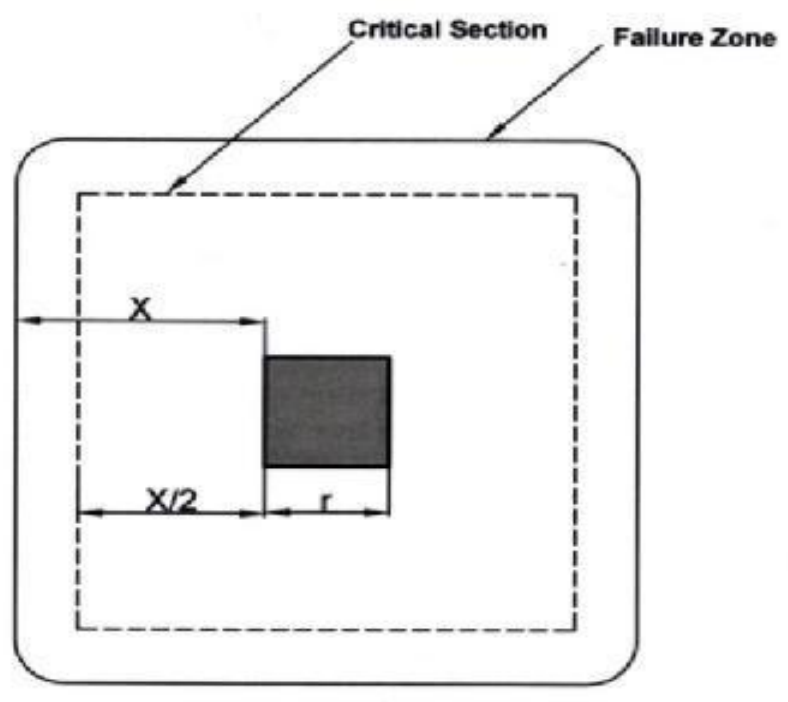

Figure (9) CRITICAL SECTION OF SLAB

$\boldsymbol{x}$-Distance between the end of failure surface and face of column

$x=105.21 \mathrm{~mm}$

\subsection{ULTIMATE FAILURE LOAD}

The use of self compacting concrete in slabs leads to significant increases in ultimate failure load. The increases of slab thickness with steel reinforcement ratio show the good result in resisting the failure.

\section{TABLE (3) ULTIMATE FAILURE LOAD FOR SLABS}

\begin{tabular}{|l|l|l|l|l|l|}
\hline $\begin{array}{l}\text { Slab } \\
\text { no }\end{array}$ & $\begin{array}{l}\text { Concrete } \\
\text { type }\end{array}$ & $\begin{array}{l}\text { Slab } \\
\text { thickness }\end{array}$ & $\begin{array}{l}\text { Steel } \\
\text { reinforcement } \\
\text { ratio }\end{array}$ & $\begin{array}{l}\text { Characteristic } \\
\text { strength }\end{array}$ & $\begin{array}{l}\text { Ultimate } \\
\text { load } \\
(\mathrm{KN})\end{array}$ \\
\hline S3 & SCC & 50 & 0.0033 & 30 & 58.5 \\
\hline S4 & SCC & 75 & 0.0033 & 30 & 78 \\
\hline
\end{tabular}

\section{RESULT AND DISCUSION}

\subsection{RESULT}

\section{LOAD DEFLECTION CHARACTERISTICS}

In this study, these slabs are identical in size, different in concrete type (SCC and $\mathrm{CC}$ ), flexural steel reinforcement ratio and slab thickness. According to these variables ultimate load, crack pattern, critical sections, angles of failure as well as modes of failure are different from one another. 
TABLE (4) LOAD DEFLECTION CHARACTERISTICS

\begin{tabular}{|l|l|l|l|l|}
\hline $\begin{array}{l}\text { SL } \\
\text { AB } \\
\text { NO }\end{array}$ & THICK & $\begin{array}{l}\text { CHARACT } \\
\text { ERISTIC } \\
\text { STRENTH }\end{array}$ & $\begin{array}{l}\text { ULTIM } \\
\text { ATE } \\
\text { LOAD } \\
(\text { KN })\end{array}$ & $\begin{array}{l}\text { MID } \\
\text { SPAN } \\
\text { DEFLECTI } \\
\text { ON (mm) }\end{array}$ \\
\hline S3 & 50 & 30 & 52.5 & 5.78 \\
\hline S4 & 70 & 30 & 67.5 & 7.22 \\
\hline
\end{tabular}

\section{OBSERVATION OF FAILURE}

Punching shear failure had occurred suddenly in all slabs. There is no sign of warning before the occurrence of failure except the rapid movement.

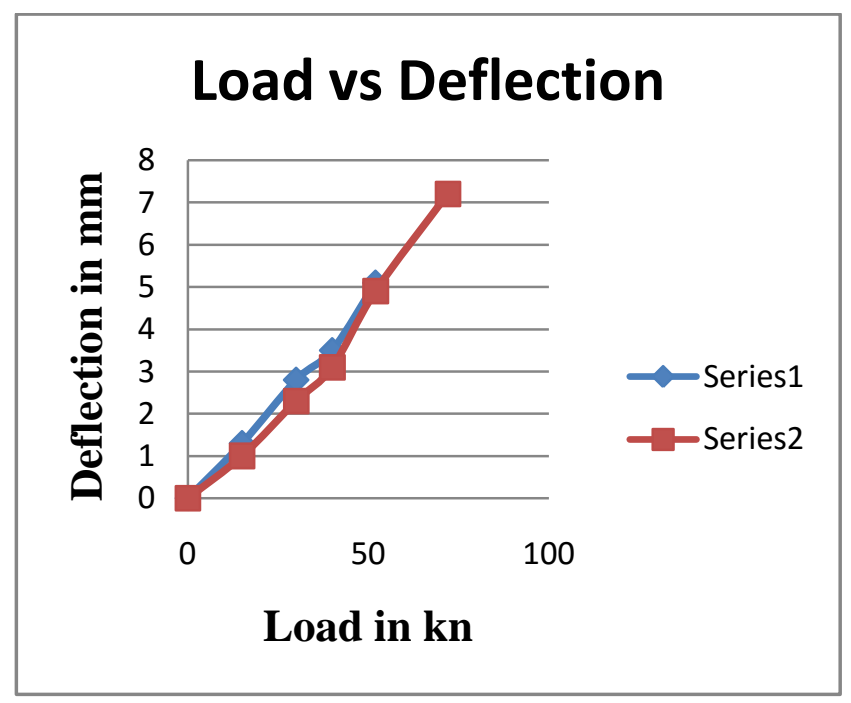

FIG 10 LOAD VS DEFLECTION CURVE

\section{CONCLUSION}

1. From the study, it was observed that the load carrying capacity and deformation at ultimate load are high in case of SCC slabs

2. The resistance of punching shear failure increases in increase of depth of slab.

3. Further, it is observed that there is reduction in the number of formation of cracks in case of SCC slab with high percentage ofckness.

4. The failure angle of SCC slabs was found to increase with increasing Vf. This indicates that the size of failure zone can be reduced by adding SCC slabs thus helping to prevent the disintegration of concrete cover under the flexural steel reinforcement.

5. Increasing slab thickness leads to increased length of such perimeter. The results of the present investigation show that the distance between the face of the column and the critical punching shear section is about (2d) for SCC slabs. 


\section{REFERENCE}

1 Skarendahl A, 2003 "The present. Proceedings of 3rd RILEM international symposium on self compacting concrete, Reykjavik", Iceland, August.Bagneux, RILEM Publications PRO 33, p. 6-14.

2 Hayakawa M, Matsuoka Y, Shindoh T. 1993. "Development and application of superworkable concrete".Proc of Int RILEM workshop on special concretes workability and mixing, Paisley, p. 183-90

3 Ali R. Khaloo and Majid Afshari.2005, "Flexural behaviour of small steel fibre reinforced concrete slabs Cement and Concrete Composites" Volume 27, Issue 1, , Pages 141-149

4 Jeffery R. Roesler, M.ASCE David A. Lange, M.ASCE Salah A. Altoubat, M.ASCEKlaus-Alexander Rieder, M.ASCE and Gregory R. Ulreich, M.ASCE52004 "Fracture of Plain and Fiber-Reinforced Concrete Slabs under Monotonic Loading" JOURNAL OF MATERIALS IN CIVIL ENGINEERING ( ) ASCE pp 452-460.

$5 \quad \mathrm{~V}$ Udhayakumar, $\operatorname{Dr} \mathrm{B} \mathrm{H}$ Bharatkumar, $\mathrm{K}$ Balasubramanian, $\mathrm{T} \quad \mathrm{S}$ Krishnamoorthy, Dr N Lakshmanan 2007, "Experimental Investigations on exural Behaviour of RCSlabs Reinforced with GFRP Rebars" Journal of Institution of Engineers Vol 88, pp 23-28

6 R.C.Gupta and Dr.M.R.Sethia 1993 "computer aided design of flat slabcolumn-footing structure", The Bridge and Structural Engineering. Vol.23 (1) pp.3954.

7 Rona9ldo B. Gomes and Paul E. Regan1999. "Punching Resistance of RC Flat Slabs with Shear Reinforcement", Journal of Structural Engineering, Vol.125 (6), pp- 684-692.

8. M.G. Sahab, A.F. Ashour\& V.V. Toropov (2005), "Cost optimisation of reinforced concrete flat slab buildings", Engineering Structures, Vol.27, pp.313-322.

9. K.M.A. Hossain, And O. Olufemi 2005. "Design optimization of simply supported concrete slabs by finite element modeling", Struct. Multidisc Optimization.Vol.30, pp.76-88.

10 H.S. Kim, And D.G.Lee2005. "Efficient analysis of flat slab structures subjected to lateral loads" Engineering Structures Vol.27 pp.251-263.

11 N. Subramanian 2005. "Evaluation and enhancing the punching shear resistance of flat slabs using HSC", The Indian Concrete Journal, Vol. 79(5), pp.3137.

12 S.S.F. Mehanny, B.M. Sobhy and M.M. Bakhoum 2008."Strength versus drift limitation effects on code compliant seismic-resistant flat slab buildings", The Indian Concrete Journal .vol.36 (6) pp.-1-2.

13Miguel Fernández Ruiz, Aurelio Muttoni, and Jakob Kunz2010, "Strengthening of Flat Slabs Against Punching Shear Using Post-Installed Shear Reinforcement", ACI Structural Journal, Vol.107 (4), pp. 434-442.

14 M.A. Eder, R.L. Vollum, A.Y. Elghazouli, T. Abdel-Fattah 2010. "Modelling and experimental assessment of punching shear in flat slabs with spearheads", Engineering Structures.Vol.32, pp.3911-3924. 
15 Vikunjk.TilvaProf.B.A.Vyas and Assit.Prof. ParthThaker 2011 "Cost comparison between flat slabs with drop and without drop in four storey lateral load resisting building", National Conference on Recent Trends in Engineering \& Tech. pp1-5.

16 Adeola A Adedeji 2011. "Application: simplifying design of RC flat slab using taboo search", Trends in applied science research (Academic Journals Inc.)Vol.6 (4) pp 375-385.

17Alaa G. S. and Walter H.D. 1998, Analysis and Deflection of Reinforced Concrete Flat Slabs, Canadian Journal of Civil Engineering, Vol. 25.

18 Moe, J. 1961 "Shearing Strength of Reinforced Concrete Slabs and Footings Under Concentrated Loads", Portland Cement Association, Research and Development Laboratories, Bulletin D47,

19 Pereira, N. B., Barros, A. O., and Camoes, A. 2008 "Steel Fiber Reinforced SelfCompacting Concrete: Experimental Research and Numerical Simulation"Jornal of Structural Engineering ASCE, Vol 134, No.8 , pp. 1310-1321.

20 Ali, S.A. 1979, "Effect of Fiber Reinforcement on the Punching Shear of Flat Plates", Ph.D. Thesis, Sheffield University,

21 Tuan, N.D.," Punching Shear Resistance of High Strength Concrete Slabs", Electronic Journal of Structural Engineer, Department of Civil and Environmental Engineer, 